\title{
Job performance: Working conditions of urban teachers in Zimbabwean schools
}

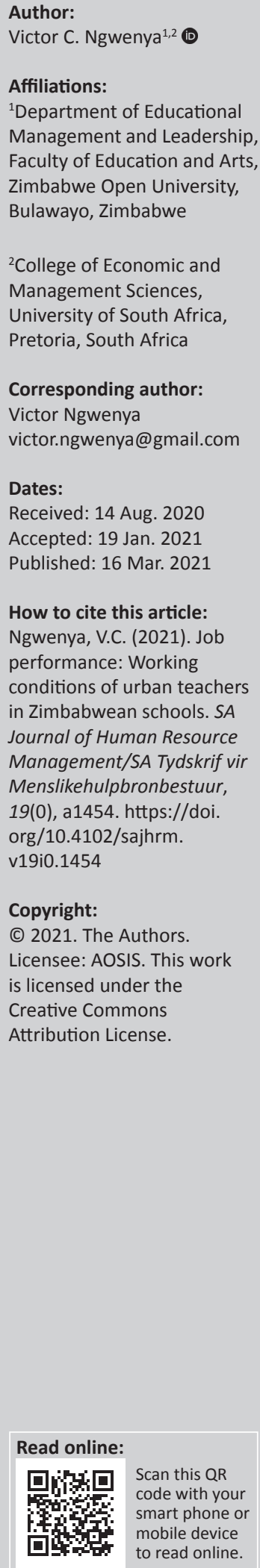

Orientation: For Zimbabwean schools to deliver quality education in this competitive and hyperinflationary environment, teachers must be paid a living wage, which is commensurate with their noble profession to spruce up their public image and retain the best.

Research purpose: The research established the Zimbabwean urban teachers' working conditions, which affected their job performance and proffered remedies.

Motivation for the study: Schools with favourable working conditions attracted, developed and retained highly qualified, experienced and effective teachers. The opposite resulted in low productivity, high turnover, absenteeism, moonlighting, job hopping and attrition.

Research approach/design and method: A qualitative approach informed by a constructivist grounded theory was used. Sixteen experienced teachers and four education managers had their lived experiences on the phenomenon under investigation interrogated as experienced in Bulawayo Metropolitan Province (BMP).

Main findings: The findings suggested that the improvement of the teachers' working conditions enhanced their job performance. Teachers bemoaned the low remunerations that could not meet their basic physiological needs, which were fundamental in enhancing their job performance. They also claimed that the teacher to learner ratio and curriculum demands overworked them amid the scarcity of resources. Sponsored career development opportunities were unavailable.

Practical/managerial implications: Improving the working conditions of teachers would not only enhance their job performance but also reduce high turnover, attrition rate and moonlighting, which has become a malaise in Zimbabwean schools.

Contributions/value-add: The study revealed that improving the remuneration for teachers has a domino effect on their poor working conditions.

Keywords: job performance; teacher burnout; teachers' working conditions; motivational factors; turnover.

\section{Introduction}

The tradition in Zimbabwe is that after teachers have completed their initial professional training, they are deployed to all parts of the country by the Ministry of Primary and Secondary Education (MoPSE) with equity in mind so that quality teachers are equally distributed nationwide in pursuit of universal primary education (UPE), which was declared at independence (Government of Zimbabwe [GoZ], 2020). However, those who are usually deployed to remote schools, which are sometimes inaccessible, encounter challenges.

The low remuneration that teachers receive in sub-Saharan Africa as compensation for a day's work has made them lose the respect, which was associated with the nobility of the profession as they fail to satisfy their basic physiological needs compared with their counterparts in the private sector (Marinette, 2018; Ohide \& Mbogo, 2017). It is this challenging environment that they operate in, made worse by the workload, decision-making, lack of support for professional development and disrespect from government, parents and community at large, which seems to affect the job performance of urban teachers in Zimbabwean schools (Adedeji \& Olaniyan, 2011). Consequently, many teachers, usually those deployed away from their home, try by all means to move closer with the hope of lessening budgetary expenses (Choy, 1996). Whilst those who fail to do so either leave the noble profession totally or pursue other endeavours locally, in neighbouring countries and in the diaspora in search of greener pastures, thus causing a high rate of teacher attrition (Adebayo \& Gombakomba, 2013; Marinette, 2018). Zimbabwean schools have lost 
dedicated, talented, experienced teachers with degrees particularly in mathematics and science out of such frustrations (Adebayo \& Gombakomba, 2013). It is against this backdrop of poor remuneration and working conditions such as those highlighted here that the study sought to investigate the impact of working conditions of Zimbabwean teachers on their job performance.

\section{Orientation}

The study is anchored on the management and motivation theories of Taylor, Grant, Elton Mayo, Maslow and Herzberg (Alonge, Onnoh, Olusesean, Ojo, \& Nahaniel, 2020). Taylor and Grant in their works opined that workers' job performance is motivated by salaries and incentives (Alonge et al., 2020; Stoner, Freeman, \& Gilbert, 2008). However, during the Human Relations era, Elton Mayo and Fritz Roethlishberger's Hawthorne experiment refuted that money and working conditions were motivators (Deckers, 2010). Instead, the experiment revealed that workers were motivated by the accomplishment of individual needs.

However, Maslow's hierarchy of needs and Herzberg's twofactor theory established that at the lowest level, the teachers' needs which would stabilise the working environment are the attainment of physiological needs, good salaries or wages, working conditions such as pensions, medical insurance, physical workplace, job security, safety needs, social needs, tenure, company policy, work ethics, organisational politics, quality of leadership, relationships amongst teachers and supervisors (Everard \& Morris, 1996; Ngwenya, 2015; Owens, 1995). The acquisition of the basic needs of physiological, safety and love lays a firm foundation for the attainment of higher order ones (Govender \& Bussin, 2020). Little wonder that, Herzberg referred to them as maintenance or hygienic factors, which must be present in the working environment for job performance to take place (Stoner et al., 2008).

Therefore, the teachers' working conditions are essential to customer satisfaction and job performance in a competitive environment (Eluka \& Okafor, 2015). In corroboration, the Nigerian study revealed that dynamic and progressive schools would endeavour to attract and retain the right teachers for the job at the right time by creating and sustaining their motivation in the changing circumstances (Eluka \& Okafor, 2015). Likewise, a Cameroonian study concurred with Maslow's and Herzberg's findings by revealing that the job performance of teachers came from wages, work environment factors, mentoring, promotional opportunities, cooperation and membership of working groups (Amin, 2015). Herzberg goes further to aver that if physical conditions are negative it can negatively impact the job performance of teachers (Deckers, 2010).

Maslow and Herzberg's observation is noteworthy which asserts that if the basic needs are not met that lay a firm foundation for the attainment of higher order needs such as responsibilities, opportunities for growth, achievement, recognition and advancement, it would be difficult for education managers to enhance the job performance of teachers in a school (Ngwenya, 2015). Hygiene or maintenance factors are extrinsic whilst motivators are intrinsic (Alonge et al., 2020). Both scholars further assert that to enhance the job performance of teachers, the prerequisite factors which constitute the working conditions and are extrinsic in nature must exist first if motivators/ higher-order needs are to be attained.

In a similar fashion, Heathfield (2019, para. 2) opined that 'in order for employers to create an environment for employee satisfaction that can aid performance in a workplace, it is vitally important to know which key factors affect employee satisfaction'. Based on this assumption, 21st-century employers are advised to take a keen interest in the improvement of the working conditions of teachers to enhance their productivity and performance levels (Amin, 2015). Although such an endeavour must not be taken for granted, expenditures on improving the working conditions of teachers are investments and these investments have to be financed (Eluka \& Okafor, 2015).

Generally, teachers value working conditions as essential ingredients to their satisfaction requiring regular maintenance and replacement of facilities (Eluka \& Okafor, 2015). Routine hardships faced by teachers in the working environment make them go job-hopping or moonlighting searching for conveniences, which may later on lead to work abandonment so as to avoid stress (Eluka \& Okafor, 2015). It is circumstances such as these that led the Nigerian study to postulate that the quality of the working environment in a school is a critical factor and may simply determine the level of teachers' motivation, subsequent performance and productivity (Eluka \& Okafor, 2015). Hence, in this study, teachers are regarded as the most valuable resource and asset needed in the school environment (Amin, 2015).

\section{Motivation of the study}

The socio-politico-economic hardships experienced by the Zimbabwean government in the past three decades have resulted in education being underfunded, with dire consequences on the teachers' poor working conditions (Mabhoyi, 2020). Hardest hit are the rural schools that were grossly affected by the 2000 violent land redistribution and the heavily contested 2008 elections, which resulted in the Government of National Unity (Mthiyane \& Chiororo, 2019). Many teachers during this era were abducted, tortured or beaten to death (Hove \& Chenzi, 2020) leading to an exodus of approximately 1.2 million people (teachers included) to neighbouring countries in search of greener pastures (Crush, 2012). Some fled from poverty, disease and economic suppression. The migration benefited South Africa the most. It received more than 10000 teachers of which 400 were mathematics and science teachers (Mlambo \& Adetibu, 2020). However, the unfortunate ones ended up doing menial jobs for survival, which is 
a disinvestment in human capital to the Zimbabwean government.

Likewise, teachers who remained behind were forced by circumstances to develop survival strategies. To cushion themselves from the effects of the prevailing hyper inflationary environment, some teachers either went moonlighting in the informal market or commercialised education. Commercialisation of education is when teachers engage learners for private gains other than their normal salary or allowance (Tarisayi, Munyaradzi, \& Chidarikire, 2020). These extra lessons are usually charged in US $\$$, not the local currency (Munikwa \& Mutungwe, 2011). Although the practice is akin to the Ugandan experience as it boosts the pass rate of learners, Zimbabwean teachers seemed to abuse it (Munikwa \& Mutungwe, 2011).

New concepts were being introduced at such platforms to market extra lessons and those who could not afford them missed out (Tarisayi et al., 2020). The practice had become more of a business activity resulting in government banning it (Tarisayi et al., 2020). Such unprofessionalism, including selling of snacks and sweets by some teachers during business hours, makes the profession unattractive to most recruits who usually settle for it as a profession of last resort (Evans \& Yuan, 2018).

However, the Teachers' Union argued that teachers engaged in second jobs for financial freedom from a life of drudgery and servitude, which was being worsened by their poor salaries and working conditions (Macleod, 2016). Similar sentiments are echoed by Hunger, Morosini and Stobaus (2016) who postulated that teachers as human beings too are not immune to the pressures of a consumer society needing other sources of income or jobs. For that reason, improving the working conditions of Zimbabwean teachers is inevitable if their productivity and performance levels are to be enhanced at their workplaces.

The assumption of this study is that salaries and working conditions of teachers have a motivating effect on their job performance, both intrinsic and extrinsic (Mabhoyi, 2020). Teachers, according to Hanke (2019), seem to have been earning worthless salaries that have been eroded as a result of harsh inflation episodes of the past. Officially, Zimbabwean teachers are supposed to be paid in US\$ but their salaries are only paid in Bond Notes (surrogate currency) and real-time gross settlements (Mabhoyi, 2020). In the financial market, the Bond Note is vulnerable to hyperinflation against the US\$. Confronted with such an economic crisis, teachers argue that their salaries have further shrunk because of the prices of basic commodities, which are officially quoted in US\$ but treble when the buyer uses Bond Notes, thus reducing one's buying power (Mabhoyi, 2020). It is not surprising that McMahon (2018) argued that Zimbabwean salaries are not inflation risk protected, hence the appalling teachers' working conditions.

Zimbabwean teachers, in turn, perceive taking up teaching as akin to taking some vow of poverty (Mabhoyi, 2020). In corroboration, Ferreira (in Mabhoyi, 2020) goes further to argue that the liberation of the educational sector in 1992 deregulated the employment of teacher recruitment as many qualified teachers from colleges were not guaranteed of jobs leading to unemployment and underemployment. Poverty is manifested in teachers' failure to access medical treatment in Zimbabwe where doctors and pharmacies either demand payment in US\$ or cash up front (Mabhoyi, 2020), making the livelihoods of the terminally ill and those suffering from chronic diseases unbearable. It becomes worse when the small clique of the ruling elite can afford international medical care sponsored by the Reserve Bank of Zimbabwe whilst the majority of teachers languish in poorly resourced public hospitals and clinics as observed by Moyo (in Mabhoyi, 2020).

Kakande's (2015) study further painted a gloomy picture of what teachers experience as a result of induced poverty when he points out that their families were on a brink of eviction for non-payment of rent and struggled over the usual basics including paying school fees for their children. What this means is that the salaries of teachers have stagnated over years, yet prices of basic commodities escalate on a daily basis (Kennedy, 2012). The failure by government to compensate teachers adequately has degraded the profession into an underground subgroup of financially stressed workers who are genuinely driven into debt to make ends meet (Macleod, 2016).

The collective bargaining negotiations are noteworthy, which characterise the beginning of every school term. Government in its attempt to avert a teachers' strike usually makes offers, which it fails to fulfil timeously. On the contrary, teachers feel that government does not want to pay them a decent salary so as to keep them neutralised by poverty and alienated as an intelligentsia class (Mabhoyi, 2020). Mandel's (2017) study confirmed this sentiment when he opines that the Zimbabwean government probably borrowing from the Russian government's hatred of intelligentsia such as teachers could be doing so deliberately to dissuade them from democratic and socialist debates, which paint rulers as dictators. Shonk (2019) in reiteration asserted that such negotiations are usually in bad faith and government never establishes a rapport with teachers but only does so to confirm that it wields power and control over their careers and work environments.

Such behaviour by government could probably be one of the reasons frustrating Zimbabwean teachers because each time they raise genuine complaints on working conditions, which affect their job performance, their concerns are disregarded, instead they are lectured on patriotism and the liberation war against the imaginary threat of imperialist America and Britain (Mabhoyi, 2020). What the government seems to be forgetting is that patriotism is not a currency and does not pay the teacher's bills. As a result, salary negotiations have become a perennial labour issue leading to clashes and failure of negotiations between the Zimbabwean government and the teachers' union (Hunger et al., 2016). Teachers, in turn, basing their argument on Adam's equity theory, further argue that whatever salary adjustments government awards them are comparatively lower than other jobs, which demand the same 
training and qualifications as theirs (Ohide \& Mbogo, 2017). Without doubt, the researcher is convinced that a wellcompensated teaching force will enable government to attract, retain and motivate high-quality teachers who will deliver education effectively (Hutton, 2011). In agreement, Eluka and Okafor (2015) posited that schools must know how to manage a diverse group of workers such as teachers because this aids in recruitment and retention of talented teachers and ensures a high level of job performance.

\section{Objectives of the study}

The specific objectives of this study were:

- To identify and describe the working conditions, which affect the job performance of teachers in Zimbabwean schools.

- To suggest remedies that may be adopted by the Zimbabwean schools and government in improving the working conditions of teachers and their job performance.

\section{Literature review}

In order for schools to deliver high-quality education, they must attract, develop and retain effective teachers by improving the working conditions (Choy, 1996). It has been proven in the United Kingdom that schools that offer their teachers a safe, pleasant and supportive working environment and adequate compensation are better able to attract and retain good teachers and motivate them to do their best (Choy, 1996). Therefore, the working conditions of teachers do not only affect their production levels but also the performance of the learners as well (Amin, 2015). The large classes and disruptive learners that teachers attend to, the geographical location of the school coupled with the low salaries they receive are some of the working conditions that affect their motivation and job performance in sub-Saharan African schools (Amin, 2015; Mabhoyi, 2020). Before looking at the working conditions of teachers as they impact their job performance, the terms 'working conditions' and 'job performance' need elucidation.

\section{Working conditions}

According to Gerber, Nel and Van Dyk (in Eluka \& Okafor, 2015 , p. 2), working conditions 'are created by the interactions of employees with their organisational climate' including the psychological working environment and the physical layout of the job. On the contrary, Eluka and Okafor (2015, p. 2) go further to view these as 'seen in the light of facilities that aid employees whilst at work for their convenience and comfort on their job performance'. These definitions seem to focus on work-related and workplace issues.

\section{Work-related and workplace issues}

Work-related issues amongst many entail a fair salary and benefits, professional development of young employees, brain drain caused by retirement leading to a talent gap and job-hopping (Portland Community College, 2015). These issues need addressing in order to recruit the best teachers or retain them. On the contrary, a workplace is 'a location at which an employer provides work for the employee, a place of employment' (Heathfield, 2019, para. 1). Kahn (in Eluka \& Okafor, 2015) further views it as a complex teaching environment with different challenges such as work overload and underutilisation, being subjected to conflicting demands by school authorities, which may destruct teachers from executing their core business of teaching. In short, a school's workplace is the physical, social, technological and psychological environment in which teachers in their different capacities interact all the time with their learners, peers, superordinates and teaching and learning resources for the purposes of attaining common goals. This feat is achievable when the working environment is favourable. In turn, their remuneration must be commensurate with their efforts (Ohide \& Mbogo, 2017). In other words, the type of compensation they get at the end of the day will either enhance their job performance or not. It is not surprising that Greenslade and Paddock (in Eluka \& Okafor, 2015, p. 2) view working conditions as 'encompassing a wide range of issues from work itself to sanitary facilities and other conveniences that aid employees in the discharge of their responsibilities'. That is why working conditions are believed to lay the foundation for job performance to take off. They are also crucial in averting teachers' burnout, absenteeism, high turnover and stress (Steyn, 1996).

\section{Job performance}

Motowidlo and Kell (2012, ch. 5) perceived it 'as the total expected value to the organisation of the discrete behaviour over a standard time'. Similarly, WiseGEEK (2020, para. 1) views it as: 'the sum total of workers' execution of assigned tasks'. Therefore, job performance is how effective and efficient teachers execute a given task within an allocated timeframe against benchmarks set by the school. Those who meet or exceed the targets set will be performing according to expectation, below that they will be underperforming.

\section{Teachers' working conditions}

As education by any standards is a bedrock of any developing nation and teachers play a critical role in nurturing the minds and hearts of the youth who are regarded as the leaders of tomorrow (Adebayo \& Gombakomba, 2013), there is need, therefore, to improve the working conditions, which affect their job performance so as to retain them. Studies conducted in Europe and subSaharan Africa established that the teachers' working conditions discussed here affect their job performance (Adebayo \& Gombakomba, 2013; Adedeji \& Olaniyan, 2011; Choy, 1996; Evans \& Yuan, 2018).

\section{Workload}

Workload which is the official teacher/learner ratio versus the real one on the ground is also of significance. 
Although the official teacher to learner ratio in the subSaharan Africa stands at 1:40 according to the World Bank Report (Adedeji \& Olaniyan, 2011), many countries, including Zimbabwe, exceeded it by far because of the UPE policy, which was introduced at independence (Evans \& Yuan, 2018). Ngwenya's (2020) study revealed that Zimbabwean classes at early childhood development level ( $0-4$ years) had an average size of 1:48 instead of 1:20 and grades 1-2 (5-6 years) had 1:56 instead of 1:40. It is the UPE policy that led to large classes that had dire consequences on resources (Evans \& Yuan, 2018; Shirrell \& Reininger, 2017). It also led to overcrowded classrooms, more teaching periods and more non-teaching activities such as extra-curricular activities. In addition to that, teachers are made to spend more hours at work, prepare lessons after school, carry work to mark at home and conduct remedial lessons, which they find straining (Alonge et al., 2020; Evans \& Yuan, 2018). In some extreme cases, teachers must contend with teaching multigrades (i.e. composite classes) or double shifting (i.e. hot-sitting) (Evans \& Yuan, 2018).

\section{Compensation}

Generally, worldwide, salaries are paid according to qualification and experience but not what teachers are able to do (Choy, 1996; Evans \& Yuan, 2018). Although in countries such as Indonesia, teaching has been found to be an attractive profession because of the salaries offered (World Development Bank, 2013) and a fairly remunerated job in Lesotho, Zambia and Sierra Leone (Evans \& Yuan, 2018), in Zimbabwe it is a different case. Adebayo and Gombakomba (2013) claimed that Zimbabwean teachers ever since 2008 when the country experienced high inflation rates, which eroded the purchasing power of their salaries, have failed to earn a living salary. A living salary in this respect must enable teachers to provide for essential needs, establish dignified living conditions for them and their families (Drussilla, Brown, Deardorff, \& Stern, 2004). Essential needs which should constitute their working conditions comprise housing, energy, nutrition, clothing, healthcare, education, potable water, childcare, transportation and savings (Alonge et al., 2020; Drusilla et al., 2004; Nhundu, 1999). Such working conditions if conducive enhance the teacher's productivity and job commitment (Alonge et al., 2020; Chireshe \& Shumba, 2011).

\section{Support for teachers' professional development}

Generally, studies conducted in the sub-Saharan Africa have revealed that teachers yearn for self-actualisation, which is not only associated with realising their full professional potentials, but positioning themselves for future promotions as well (Drusilla et al., 2004; Harris, Davies, Christensen, Hanks, \& Bowles, 2019). Further to that they have been found to pursue these opportunities for growth with vigour if they are supported by organisations that hire them (Alonge et al., 2020), a situation which obtains in developed countries as well (Choy, 1996). On capacity building programmes, the MoPSE in Zimbabwe demands that teachers with diplomas upgrade themselves to degree status for the effective implementation of the new curriculum framework (GoZ, 2015). Attempts to upgrade the professional status of teachers that were government sponsored before the launch of the new curriculum were initiated in 2014 (GoZ, 2015). However, with time the exercise was abandoned because of lack of funds although with negative consequences on the implementation of the new curriculum in terms of professional pedagogy, teacher morale and attrition. The latter is confirmed by a study conducted in South Sudan which revealed that high attrition caused by lack of growth opportunities is prevalent in many African schools (Ohide \& Mbogo, 2017).

\section{School decision-making}

According to studies conducted in developing countries, teachers in smaller schools were found to be more engaged in the formulation of school policies and school affairs than their counterparts in larger ones (Adedeji \& Olaniyan, 2011). Where they were excluded, they felt ignored and powerless in their efforts to improve the learning experiences of learners, despite their desire and enthusiasm (Adedeji \& Olaniyan, 2011). Participation in the decision-making process enhanced their commitment and job performance (Harris et al., 2019; Shirrell \& Reinenger, 2017). Furthermore, a study conducted in sub-Saharan Africa revealed that the majority of teachers investigated wanted autonomy in the classroom and control over setting of a disciplinary policy, curriculum issues and determining the content of in-service programmes (Adebayo \& Gombakomba, 2013; Alonge et al., 2019; Shirrell \& Reininger, 2017). However, very few claimed to have control over the disciplining of learners, deciding what was taught and selecting instructional materials (Ohide \& Mbogo, 2017). Despite that, they claimed to have control over evaluating and grading of learners, selecting teaching techniques and determining the amount of homework assigned (Adebayo \& Gombakomba, 2013; Shirrell \& Reininger, 2017).

\section{School safety and working environment}

Teachers deployed in crime-ridden areas felt unsafe as their security was not guaranteed (Evans \& Yuan, 2018). They even feared that learners' behaviour which could be wayward at any given time, a situation if worsened by drug and alcohol abuse, has the potential to disrupt their working environments (Adebayo \& Gombakomba, 2013). However, on the positive note, studies in developing countries have revealed that positive working environments play a very crucial role for teachers' physical, mental and emotional health (Evans \& Yuan, 2018). To enhance the job performance of teachers, such workplaces must be closer home, comfortable, clean, have adequate teaching and learning materials, good infrastructure with adequate working space in wellventilated classrooms, high-quality furniture and subsidised food (Alonge et al., 2020; Evans \& Yuan, 2018). Evans and Yuan's (2018) study even goes further to note that many teachers in Mozambique, Delhi, South Africa and Angola could not give their best because their learners sat on floors, classrooms were either in corridors or under the trees, respectively. Equally frustrating was the situation in Uganda 
and Zimbabwe where the shortage of textbooks affected the effective and efficient implementation of the national curriculum. In Uganda, the textbook/learner ratio was 1:14 whilst in Zimbabwe because of the introduction of the new learning areas, which never existed before, it was 1:40 (Ngwenya, 2020). It is working conditions such as these which have been found to impact the job performance of teachers which this study intends to investigate.

\section{Learners' readiness to learn}

Several studies in African countries have revealed that the acquisition of knowledge and skills is affected by the use of the coloniser's language as an official medium of instruction. Along that school of thought, Zimbabwe introduced 16 official languages, including sign language to facilitate the provision of inclusive, equitable and equal education (GoZ, 2013, 2015), particularly in mathematics and science where many learners are faced with challenges (Adebayo \& Gombakomba, 2013; GoZ, 2020). Despite the adoption of indigenous languages that many scholars thought aided learners' readiness to learn, teachers' job performances were still hindered by learners who came to school without exercise books, completed homework, pens and pencils (Adebayo \& Gombakomba, 2013). This, in turn, affected the efficient and effective attainment of organisational goals.

\section{Relationships with superiors and colleagues}

Generally, the leadership style and supervisory practice used by education managers in their interactions with subordinates have been found to affect the job performance of teachers (Harris et al., 2019; Shirrell \& Reininger, 2017). In such situations, education managers are advised to be both task and human related if they are to get the best out of their teachers (Alonge et al., 2020). Partnership engagements between the two parties are also encouraged if organisational goals are to be achieved as expected. However, goal incompatibility between education managers and teachers and the criteria used for evaluating and rewarding teachers if not checked may be stressful and conflicting (Alonge et al., 2020). On the contrary, the structure of the school set up itself with its subdivisions into smaller units; isolates teachers from their colleagues with little opportunity for interaction (World Bank, 2016). In such circumstances, peer supervision is non-existent and teachers have limited cooperation amongst themselves because of the nature of their job, which affects their job performance in the long run (Alonge et al., 2020).

\section{Public respect for teachers}

In the past, teaching has been highly revered and considered a noble profession (Marinette, 2018). However, in recent decades the status of teachers across the world seems to have declined in terms of pay, respect and working conditions (Evans \& Yuan, 2018). Moorj (in Evans \& Yuan, 2018, p. 21) confirms this observation in 'Teaching as a profession no longer enjoys the high social prestige as it did 30 years ago'.
It is not surprising that in most African countries, the teacher's status is similar to social workers or librarians, except in China where it is equivalent to doctors (Evans \& Yuan, 2018). Foreign teachers teaching in international schools in China enjoy numerous perks such as flight allowance, furnished apartments, paid holiday and health insurance (Mlambo \& Adetibu, 2020). In Zimbabwe, the status of teachers was seriously eroded during the high inflation experienced in the past such that some teachers abandoned the noble profession in order to do menial jobs as highlighted before (Adebayo \& Gombakomba, 2013). Previous solutions by policy-makers in the past have been to recruit more teachers to replace those who will have left, which has never been a viable solution (Harris et al., 2019). It is this lack of public respect which has made teaching, a profession of last resort as alluded to before as many would-be graduates disrespect it and many parents would not even encourage their children to take it up as a career (Evans \& Yuan, 2018). Such a state of affair does not only affect the job performance of Zimbabwean teachers, but engenders high turnover and attrition rate, hence this investigation.

\section{Research methodology}

The epistemological methodology used was informed by constructivism. The ontological position was anchored on relativism which assumes that knowledge is a product of human interaction as opposed to realism (Denscombe, 2014). Resultantly, the researcher attempted to socially and culturally construct knowledge based on the lived experiences of the participants and interactions with others in a given context (Creswell, 2018). As the study sought to have a deeper understanding and interpretation of the subjective world of human experience, its complexity and multiple realities (Charmaz, 2014), a constructivist paradigm was used. The assumption was based on the belief that there is no objective knowledge which is independent of thinking and reasoning by humans, so knowledge and meaning are acts of interpretation between the participants and the researcher (Creswell, 2018).

\section{Research approach}

A qualitative approach was utilised in an attempt to explore and understand the central phenomenon better (Denscombe, 2014). It was also used to observe and interpret reality with the aim of developing an explanation and a theory on what was being experienced by teachers in their workplaces (Creswell, 2018).

This further helped in the understanding of the teachers' working conditions within their social and cultural context from their voices and perceptions better (Charmaz, 2014). The adoption of this approach was based on the assumption that it is humanistic, naturalistic, holistic and is concerned with how the social world is interpreted, understood, experienced, produced and constituted by the participants and the interaction of the researcher (Creswell, 2018). 


\section{Research method}

A constructivist grounded theory which is rooted in pragmatism and is inductive in nature was used to generate data (Charmaz, 2014). The intention was to generate theory grounded in pragmatic observations and the participants' experiences (Charmaz, 2014). Data derived from experiential engagements and direct contacts with the participants were reported using thick descriptions based on the emergent themes (Denscombe, 2014).

\section{Research setting}

The study was conducted in the Bulawayo Metropolitan Province (BMP) which is the second largest city in Zimbabwe and is subdivided into five operational districts. The province is home to about 128 primary schools, 48 secondary schools and numerous higher institutes of learning. Historically, Bulawayo has been the industrial centre and the hub of the National Railways network. However, the economic meltdown that has led to the closure of many industries has had a negative bearing on the working conditions of teachers. Parents in partnership with government play a major role in the provision of education in Zimbabwean schools (GoZ, 1998). They construct schools, provide teaching and learning materials, equip specialised classrooms, fund sporting activities and depending on their financial capabilities, provide incentives for teachers amongst many of their responsibilities. It is the lack of financial power by some parents coupled with the hyperinflation rate of the economy that has grossly affected the working conditions of teachers in the BMP (Wikipedia, 2020).

\section{Entry and establishing research roles}

Permission to conduct the study was sought from the MoPSE. The approval letter was used to seek permission from the Provincial Education Director of the BMP. Further permission was sought from the District Inspector and education managers of the Cluster Schools, which were investigated. Before any fieldwork was undertaken, ethics clearance was sought from the Zimbabwe Open University. Ethical issues observed entailed human dignity, privacy, confidentiality and anonymity. Thereafter, participants were briefed about the potential benefits of the research and the physical, psychological, social, economic or legal harm that they would experience by participating in this research. They were assured that, in the event adverse effects were experienced, peer debriefing and counselling would be employed. All these efforts were meant to solicit their voluntary consent. Consenting participants were made to sign consent forms. Then, appointments for interviews were made. During the interview, the researcher's prejudices and biases were minimised by focusing on the research questions.

\section{Research participants and sampling method}

A non-probability sampling method was utilised involving a combination of purposive and snowball sampling techniques in selecting 16 consenting teachers. Initially, five senior teachers who had served the longest in each District Schools were deliberately selected. In a snowball fashion, the interviewee was requested to nominate another senior teacher with similar lived experiences of his or her working conditions within the jurisdiction of the BMP because the intention was to delve in-depth on exploring the specifics of the phenomenon (Best \& Khan, 2014). This made it easier, economic and quicker to generate volumes of data within a short space of time (McCombes, 2020). The views of the teachers were cross-checked with those of four education managers who were equally selected purposively giving a sample of 20. The sample size was determined by theoretical saturation and was considered adequate (Silverman, 2016). Here is the demographic data of the participants.

Table 1 reveals that the composition of the major participants comprised five males and 11 females portraying how the urban deployment of teachers is gender biased. All participants were degree holders with 10 of them having studied management. Amongst these was participant 2 with a $\mathrm{PhD}$ degree. Their teaching experiences ranged from 14 to 32

TABLE 1: Biographic data of participants.

\begin{tabular}{|c|c|c|c|}
\hline Participants & Gender & Professional qualifications & Experience in years \\
\hline 1 & Male & Bachelor of Educational Management & 15 \\
\hline 2 & Female & Doctor of Educational Management & 28 \\
\hline 3 & Male & Bachelor of Educational Management & 17 \\
\hline 4 & Female & Bachelor of Educational Management and Leadership & 17 \\
\hline 5 & Female & Master of Educational Management & 17 \\
\hline 6 & Female & Master of Educational Management & 15 \\
\hline 7 & Female & Bachelor of Educational Management & 28 \\
\hline 8 & Male & Bachelor of Guidance and Counselling & 28 \\
\hline 9 & Female & Bachelor of Education & 24 \\
\hline 10 & Female & Bachelor of Education & 26 \\
\hline 11 & Male & Bachelor of Science and Agriculture & 23 \\
\hline 12 & Female & Bachelor of Educational Management & 18 \\
\hline 13 & Female & Bachelor of Education in English & 20 \\
\hline 14 & Male & Bachelor of Arts & 14 \\
\hline 15 & Female & Bachelor of Educational Planning and Policy Studies & 32 \\
\hline 16 & Female & Bachelor of Educational Management & 15 \\
\hline
\end{tabular}


years with half of them having taught for more than 20 years. The data generated from the teachers on the same phenomenon were triangulated with that from the four education managers of the same schools who were equal in gender. Two of these had a Master's degree whilst the other two had first degrees. All of them had been in that post for more than 10 years. Judging by the qualifications and experiences of the 20 participants, the researcher was convinced that their responses would yield credible, dependable, transferable and confirmable data (Korstjens \& Moser, 2018).

\section{Data gathering methods}

A semi-structured interview protocol with open-ended questions comprising three key questions was used: (1) what does the term 'working conditions of teachers' mean? (2) How do the working conditions of teachers affect their job performance in Zimbabwean schools? (3) How can the identified working conditions of teachers be improved? To augment interview data, an observation checklist was utilised to elicit emotions, experiences and opinions from participants in a face-to-face interaction. The thematic questions encouraged the participants to give elaborated responses, which in some instances were triggered by probing. The researcher also used these to obtain a description of the teachers' life world in situ in a conversational manner with respect to interpreting the described phenomenon and in turn participants sought clarification on ambiguities (Best $\&$ Khan, 2014). In the process, the physical expressions, tone of the voice and reactions to the questions were observed for interpretation as well. The interview and empirical observation data generated were triangulated and authenticated by the four engaged education managers.

\section{Data recording}

Interview data were tape recorded and observations were captured as they occurred. A field notebook was also used to supplement the recorded data. All generated data were transcribed, de-identified in such a way that it was not traceable to the source, coded, encrypted and was archived in the hard drive of the laptop for a minimum period of 5 years. Thereafter it would be deleted permanently and hard copies containing such data would be shredded (Creswell, 2018).

\section{Strategies to ensure data quality and integrity}

Credibility of data gathered was enhanced by reporting it using thick, rich descriptions in the participants' voices using representative verbatim citations transcribed from the interviews conducted to demonstrate the connection of the data and the findings within the context. This enabled the researcher to have a shared experience with the reader and enhanced transferability (Korstjens \& Moser, 2018).

\section{Data analysis}

Raw data from the audiotape were transcribed, whereas data from field notes and the observation protocol were assembled under a framework of analysis determined by the research sub-questions (Charmaz, 2014). Data analysis occurred simultaneously with data generation through a process of constant comparison analysis and theoretical sampling (Creswell, 2018). In the process of emergent data, the researcher was sensitive to the voices of the participants. Generated data were subjected to open coding that involved reading it several times to create summaries using preliminary labels, axial coding to create conceptual families from the summaries and selective coding which turned the families into a formal framework with a variable that included all the generated data (Charmaz, 2014). Initially, a single case was investigated using a semi-structured interview protocol and participant observation to create a conceptual category, and then 19 more cases to confirm the indication followed until theoretical saturation was achieved (Glaser \& Straus, 1998). It is from this empirical encounter that the subject matter was reported under different themes from which the theory was unearthed (Denscombe, 2014).

\section{Findings}

The data analysis process yielded the following thematic areas, namely, the definition of the working conditions of teachers and job performance, demotivators, leadership, teaching and learning resources, physical and technological environment.

\section{Awareness of the working conditions of teachers and job performance}

According to the participants, the working conditions of teachers are:

'[T]he physical, safe and friendly working environment experienced by a teacher in relation to others as provided by the employer with clear laid down regulatory procedures on how duties should be executed based on one's job description within a given timeframe ... remuneration, benefits and availability of resources included.'

In summary, participants 4 and 10 perceived these as 'codified terms of employment based on the contract and labour laws of the country.'

\section{On job performance, they reported that:}

'[I]t entails how well a teacher executes his or her duties based on the job description and is usually measured by outcomes such as one's pass rate, learner discipline and class attendance.'

In concurrence, participants 7 and 9 viewed it as 'an effective and efficient accomplishment of an assigned task based on stipulated guidelines with quality as a measure of success.' Convinced that they had a conceptual understanding of the terms, the researcher then interrogated them on the teachers' working conditions, which affect their job performance and the findings are summarised in Table 2 under the emergent themes. 
TABLE 2: Research question and generated main and subthemes.

\begin{tabular}{|c|c|c|}
\hline Question & Major theme & Subtheme \\
\hline \multirow[t]{5}{*}{$\begin{array}{l}\text { Working conditions } \\
\text { which affect job } \\
\text { performance }\end{array}$} & 1. Demotivators & $\begin{array}{l}\text { 1.1 Low remuneration } \\
\text { 1.2 Lack of intrinsic and extrinsic } \\
\text { motivators } \\
\text { 1.3 Loans/accommodation } \\
\text { 1.4 Transport/housing allowance } \\
\text { 1.5 Medical aid } \\
1.6 \text { Hunger } \\
1.7 \text { In-service } \\
1.8 \text { Curriculum demands } \\
\text { 1.9 Undisciplined learners }\end{array}$ \\
\hline & 2. Workload & $\begin{array}{l}\text { 2.1 Teacher to learner ratio. } \\
\text { 2.2 Congested timetable } \\
\text { 2.3 Numerous records } \\
\text { 2.4 Multiple duties } \\
\text { 2.5 Long hours } \\
\text { 2.6 Deployment } \\
\text { 2.7 Performance appraisal } \\
\text { 2.8 Vacation leave } \\
\text { 2.9 Government policies }\end{array}$ \\
\hline & 3. Leadership & $\begin{array}{l}\text { 3.1 Unqualified/incompetent } \\
\text { 3.2 Communication skills } \\
\text { 3.3 Entrepreneurial skills } \\
\text { 3.4 Unprofessionalism } \\
\text { 3.5 Inferiority complex } \\
\text { 3.6 Harassment } \\
\text { 3.7 Favouritism } \\
\text { 3.8 Parental engagement }\end{array}$ \\
\hline & $\begin{array}{l}\text { 4. Teaching and } \\
\text { learning } \\
\text { resources }\end{array}$ & $\begin{array}{l}\text { 4.1 Inadequate } \\
4.2 \text { Unfair distribution } \\
4.3 \text { Library facility } \\
4.4 \text { Stationery } \\
4.5 \text { Connectivity }\end{array}$ \\
\hline & $\begin{array}{l}\text { 5. Physical and } \\
\text { technological } \\
\text { environment }\end{array}$ & $\begin{array}{l}5.1 \text { Insecure } \\
5.2 \text { Infrastructure } \\
5.3 \text { Hot-sitting } \\
5.4 \text { Water source }\end{array}$ \\
\hline
\end{tabular}

\section{Teachers' working conditions that affect their job performance}

\section{Demotivators}

All participants bemoaned their salaries, which they claimed to be 'below the poverty datum line' and were therefore incapacitated in one way or another in these prevailing harsh socio-economic conditions as 'prices were escalating daily'. The 'bunching of their salaries regardless of qualifications and experience' and the 'lack of rewards and incentives to motivate them both intrinsically and extrinsically' worsened their plight. Their desperate state is collectively expressed in the following words:

\footnotetext{
'Teaching is a noble profession yet we have become a laughing stock. Government must give us house loans to spruce up our image. Instead our learners are our landlords. Rentals are charged in US\$s yet my salary is in this surrogate currency. To pay ..., I rely on the black market whose exchange rate is unbearable. Then I am left with nothing to survive on and hunger rages on. I wonder why we are not paid in US\$s.'
}

Their circumstances have been worsened by their failure to access their preferred medical facilities when they fall sick as service providers either demanded 'cash upfront or US\$ payment' despite belonging to the giant medical society, which caters for all civil servants. Teachers suspected that the society may be failing to meet its financial obligations. Resultantly, they found themselves hospitalised 'in public hospitals which are poorly resourced ... many a time have no drugs or medical personnel are either on strike or go-slow.'

Likewise, participants quipped that the new curriculum demands imposed on us on a daily basis by management or the parent Ministry, amid the scarcity of resources are frustrating'. They even queried why they were supposed to upgrade their qualifications in line with the new curriculum's demands at their own expense. Instead, they suggested that 'government must fund our in-service courses and take a front seat in mobilising the much needed resources for efficient and effective implementation of the new curriculum.' Similarly, participant 9 felt that government's emphasis on 'Children's Rights' without putting measures to safeguard teachers has turned learners into unruly brutes. In concurrence, participant 5 remarked that 'these disrupt lessons willy-nilly and teachers are insecure.'

\section{Workload}

All participants felt that the current teacher to learner ratio of 1:40 was being violated by government as teachers found themselves teaching classes of up to 60 learners at the most because of the UPE policy, which compels public schools to admit learners beyond the official ratio. This scenario:

' $[D]$ ]oes not only crowd classrooms, but overworks us as well when it comes to the marking load, classroom management, the provision of teaching and learning resources and individual attention .... in the end the hallmark of the child-centred pedagogy is compromised in the process.'

Evidence on the ground testified to this phenomenon. The extra furniture in the classrooms meant to accommodate extra learners limited movement/ventilation and learners in some cases were observed sharing textbooks in the ratio of 1:5. In severe situations, it was only the teacher who had the official textbook.

When education managers of investigated schools were quizzed on this experience, their collective response was: 'government's non-exclusion policy of learners for nonpayment of fees is financially crippling the operations of our schools.'

Furthermore, participants acknowledged that the advent of the new curriculum, though noble, had brought with it new subjects, which deskilled them such as: 'Information Communication Technology, Art Displays and Agriculture'. Resultantly, most participants felt that the 'timetable was congested and overloaded'.

They even suggested that 'specialist teachers must be hired to teach specialist subjects such as Physical Education to lessen our burden'. Others further intimated that teachers should be allocated one afternoon activity over and above their teaching load to reduce the working hours, which spilled into their home time as they carried exercise books to mark, let alone with the 'suspension of vacation leave'. Furthermore, they complained about the numerous records, which were demanded by the District School Inspectors (DSIs) on their routine visits. These varied from 8 to 12 according to schools. In their view, 'some records are a duplication of the other'. 
When probed further, teachers intimated that at the most five records: 'Scheme cum Plan, Individual Progress Record, Class Register, Class Inventory and Remedial Record' would suffice. They further claimed that some records such as 'the Progress record can be combined with the Reading record'.

Participant 7, with 28 years of teaching experience, lamented the precious time teachers wasted in trying to update the records in preparation for inspection by the DSIs at the expense of teaching. When education managers were interrogated on this phenomenon, they claimed that 'these numerous records are imposed by DSIs and resisting them would result in victimisation or intimidation'. Likewise, participant 9 did not see the wisdom of completing performance appraisal forms annually as ever since the tradition started, no feedback has been received from the employer. To her, 'it has become a tick box exercise which does not add value to teaching'.

\section{Leadership}

Most participants claimed that some education managers 'are not adequately qualified for the posts or do not have a management degree ... those appointed on seniority are worse'. Participants 6 and 12 further observed that such education managers because of 'inferiority complex become unprofessional in dealing with their subordinates whom they constantly harass and undermine because they possess superior qualifications'. Participants 5, 7 and 16 also weighed in by claiming that they also 'have poor communication skills', 'lack appropriate entrepreneurial skills needed for self-sustenance in schools ... are incapable of mobilising parents to be engaged in the education of their children'. Such education managers, in participants 2, 1 and 4's perceptions, preferred 'inspection as opposed to supervision to exert their authority'. In some cases, teachers pointed out that the same education managers have 'favourite teachers who always attended Non-Governmental Oganisations' workshops with better benefits as opposed to government organised ones.

\section{Teaching and learning resources}

All participants concurred that teaching and learning resources in schools were inadequate and where they were available were unfairly distributed. Cases of vulnerable learners who could not afford stationery were also reported.

\section{Physical and technological environment}

Participant 3 claimed that some school buildings were 'anachronistic' and 'an eyesore to the public'. He could not even remember when his school was last painted for the 17 years he has been teaching there. On scrutiny, some paint and tiles were even peeling off and ceiling boards falling off in some classrooms.

Participant 10 weighed in: 'school grounds are deserts because of water shedding ... we go for a week without this precious liquid'. All participants agreed that their situation was compounded by mainstreaming of the early childhood development entity to the regular school leading to some 'libraries' being converted into classrooms and 'hot-sitting' being introduced. Surprisingly although, some urban schools lacked 'internet connectivity' in this time and age.

\section{Discussion}

Generally, Zimbabwean urban teachers and education managers who were investigated seem to be professionally qualified and experienced with one teacher being a PhD holder in Educational Management. Their definitions of working conditions and job performance revealed that they are conscious of the factors, which motivate their productivity levels and performances in their workplaces.

The findings of the study revealed that the poor working conditions in which the majority of Zimbabwean urban teachers operate in border on low remuneration as observed by the literature reviewed. Based on the equity theory, they argued that their remuneration neither enhanced their job performance nor enabled them to improve their standard of life in comparison to their counterparts in the private sector in the competitive environment they found themselves in as opined by Ohide and Mbogo (2017). Resultantly, their low earnings could not afford the basic physiological needs they needed for human survival, let alone basic commodities whose prices are pegged at black market rates. It is not surprising that some teachers professed hunger.

Disturbing, though, was the failure by schools to reward or incentivise excelling teachers in recognition of their good performance and the bunching of salaries regardless of their qualifications or experience, thus defeating the purpose of professional development as demanded by the new curriculum (GoZ, 2015), which is undertaken at their own expense. The schools' failure to provide favourable conditions that would enable teachers to acquire the basic physiological and safety needs, which are supposed to lay a firm foundation for the higher order ones, could be one of the reasons schools fail to retain the best teachers for the job, (Alonge et al., 2020; Portland Community College, 2015) more so that the quality of working environment is a critical factor, which determines the level of an employee's motivation, subsequent performance and productivity (Eluka \& Okafor, 2015).

The study also revealed that Zimbabwean teachers are overworked because of the unofficial teacher/learner ratio, which is compounded by the admission policy, congested timetable with new learning areas wherein they do not have the expertise and the allocation of various co-curricular areas that prolong job engagement. The numerous routine demands of the new curriculum which are either imposed by management or the MoPSE without due process or adequate resources as the old one undergoes metamorphosis are of significance. Likewise, are DSIs who have turned teachers into scribes by demanding numerous and conflicting 'school records' without their professional engagement.

Supervision of teachers has also become nightmarish in the hands of incompetent education managers. It is characterised 
by'inspection','victimisation','intimidation' 'unprofessionalism' and 'favouritism'. Some of them have been found to lack 'entrepreneurial skills' meant to propel schools to greater heights in this technologically advanced society.

Capital projects and mobilisation of resources in Zimbabwean schools are funded by parents in partnership with government (GoZ, 1998). The economic meltdown coupled with high unemployment and drought has led to the dearth of teaching and learning resources, dilapidated and inadequate infrastructure, 'hot-sitting' and unattractive school grounds.

\section{Limitations of the study}

The results of this study need to be interpreted with great care as the investigation was confined to the BMP utilising a small sample compatible with qualitative studies as the purpose was to explore the phenomenon within a given context not to generalise. The transferability of these findings is left to the reader to make judgements about their applicability to other comparable instances (Denscombe, 2014).

\section{Practical implications and recommendations}

Based on the findings of this study, the following recommendations are made:

Appointed education managers must have a degree in Educational Management, not subject ones, if they are to be equipped with the appropriate management software relevant to the post. Those without should be encouraged to upgrade their professional qualifications so as to match most of the professionally qualified teachers practising in Zimbabwean urban schools in order to avert the uncalled for conflicts or stresses influenced by inferiority complex. In addition, some operational areas where they are found wanting may be remedied by in-servicing them as highlighted by participant 6 and 11 .

Teachers should be paid a living wage, pegged above the poverty datum line, to enable them to survive in the Zimbabwean hyperinflationary environment they operate in to avert job withdrawals, abandonment or attrition. Funds permitting, teachers could be paid in the US\$ not the surrogate currency that only serves to fuel inflation, which stood at above $785 \%$ as of May 2020. Salaries of teachers must be de-bunched forthwith, as bunching defeats qualifications and experience differentials. In a small way, schools through parent bodies must reward and incentivise high fliers so as to motivate their job performance. In addition, they should be provided with teas and snacks to prolong their engagement at school and avert hunger.

Some related subjects, such as art displays and physical education, brought about by the new curriculum, need amalgamation to decongest the timetable. Specialist subjects must be taught by specialists to reduce the classroom practitioner's teaching load. Above all, vacation leave must be reinstated unconditionally and record books must result from a professional engagement between DSIs and teachers, not unilateral decisions, which only cause tension.

Flourishing companies must be encouraged to adopt or twin with disadvantaged schools within the communities they operate in. These will partner schools in resource mobilisation. Schools too, whilst exploiting the various entrepreneurial skills introduced by the new curriculum, must engage in various income-generating projects. However, the nonexclusion policy for non-payment of fees and levies, which appears to be politically motivated needs revision.

Government, in partnership with banks, must negotiate for soft loans to assist teachers to buy their own houses or cars to improve their public image in the society. At the worst, public transport subsidised by government could be organised for the transportation of teachers. Furthermore, cars usually allocated to government officials during their first tenure of office, if appointed for the second term since they would be entitled to another one, could be made available to teachers at affordable rates.

\section{Conclusion}

Employers of educators must know that teachers are the most valuable asset any school may have.

Therefore, they must provide a safe, pleasant and supportive working environment and adequate compensation if they are to attract and retain good teachers and motivate them. In turn, teachers regard working conditions as essential ingredients towards their job satisfaction requiring regular maintenance and replacement if their job performance is to be enhanced. In conclusion, collective bargaining negotiations between the Zimbabwean government and teachers must be conducted in good faith free of political patronage if the poor working conditions are to be improved in Zimbabwe as the net beneficiaries are learners.

\section{Acknowledgements}

The author would like to acknowledge the teachers who were the participants, education managers who are the gatekeepers of the institution, the ethics committee, the Permanent Secretary of Education and Provincial Education Director who allowed that the research be conducted in Zimbabwean schools, and finally the professional editor.

\section{Competing interests}

The author declares that he has no financial or personal relationship(s) that may have inappropriately influenced him in writing this article.

\section{Authors' contribution}

I declare that I am the sole author of this research article. 


\section{Ethical considerations}

This article followed all ethical standards for carrying out research without direct contact with human or animal subjects.

\section{Funding information}

This research received no specific grant from any funding agency in the public, commercial or not-for-profit sectors.

\section{Data availability}

The authors confirm that the data supporting the findings of this study are available within the article.

\section{Disclaimer}

The views and opinions expressed in this research article are those of the author and do not necessarily reflect the official policy or position of any affiliated agency of the author.

\section{References}

Adebayo, A.S., \& Gombokomba, T. (2013). Dimensions of teachers' job satisfaction in primary schools in Gweru District, Zimbabwe: A factor analysis. European Scientific Journal, 9(5), 309-317.

Adedeji, S.O., \& Olaniyan, O. (2011). Fundamentals of teacher education: Improving the conditions of teachers and teaching in rural schools across African countries. Addis Ababa: United Nations-International Institute for Capacity Building-Africa.

Alonge, B.D., Onnoh, O.G., Oluseseun, O.J., Ojo, O.A., \& Nathaniel, O.O. (2020) Working conditions and salary as correlates of teacher's productivity in government-owned secondary schools in Emure Local Government area of Ekiti State, Nigeria. Journal of Educational Issues, 6(1), 89-97. https://doi.org/ 10.5296/jei.v6i1.16400

Amin, M. (2015). Relationship between job satisfaction, conditions, motivation of teachers to teach and job performance of teachers in MTs, Survey, Banten. Journal of Management and Sustainability, 5(3), 141-154. https://doi. org/10.5539/jms.v5n3p141

Best, J.W., \& Khan, J.V. (2014). Research in education (11th edn.). London: Alyn and Beacon.

Charmaz, K. (2014). Constructing grounded theory (Introducing qualitative method series) (4th edn.). Thousand Oaks, CA: Sage.

Chireshe, R., \& Shumba, A. (2011). Teaching as a profession in Zimbabwe: Are teachers facing a motivation crisis? Journal of Social Science, 28(2), 113-118. https://doi.org/10.1080/09718923.2011.11892935

Choy, S.P. (1996). The condition of education: Teachers' working conditions. NCES 97-371. Washington, DC. Retrieved from www.allafrica.com

Creswell, J. (2018). Qualitative inquiry and research design: Choosing among five approaches (4th edn.). Thousand Oaks, CA: Sage.

Crush, J. (2012). Zimbabweans see a future in South Africa. Retrieved from http:// www.thenewage.co.za

Deckers, L. (2010). Motivation, biological, psychological and environmental (3rd edn.). Boston, MA: Pearson.

Denscombe, M. (2014). A good research guide: For small-scale social research projects (5th edn.). Berkshire: McGraw Hill House.

Drussilla, K., Brown, A., Deardorff, V., \& Stern, R.M. (2004). The effects of multinational production on wages and working conditions in developing countries. Chicago, IL: University of Chicago.

Eluka, J.C., \& Okafor, N.C. (2015). A critical review of the effects of working condition on employee performance: Evidence from Nigeria. Lagos: University of Nigeria.

Evans, D.K., \& Yuan, F. (2018). The working conditions of teachers in low-and middleincome countries. World Bank, World Development Report. Retrieved from https://scholar.harvard.edu/feiyuan/publications/

Everard, K.B., \& Morris, G. (1996). Effective school management (3rd edn.). London: PCP Ltd.

Glaser, B., \& Strauss, A. (1998). The discovery of grounded theory: Strategies for qualitative research. Chicago, IL: Aldine.

Govender, M., \& Bussin, M.H.R. (2020). Performance management and employee engagement: A South African perspective. SA Journal of Human Resource Management, 18, a1215. https://doi.org/10.4102/sajhrm.v18i0.1215

Government of Zimbabwe (GoZ). (1998). Statutory Instrument 378 (Amended). Harare: Author.
Government of Zimbabwe (GoZ). (2013). Constitution of the Republic of Zimbabwe. Harare: Author.

Government of Zimbabwe (GoZ). (2015). Curriculum framework of primary and secondary education. Harare: Author.

Government of Zimbabwe (GoZ). (2020). Education Amendment Act. Harare: Author

Hanke, S.H. (2019). Zimbabwe's monetary death spiral. Retrieved from https:// www.cato.org/

Harris, S.P., Christensen, S., Hanks, J., \& Bowles, B. (2019). Teacher attrition: Differences in stakeholders' perceptions of teacher work conditions. Education Sciences, 300(9), 1-11. https://doi.org/10.3390/educsci9040300

Heathfield, S.M. (2019). What you need to know about workplaces for employees? Retrieved from https://www.thebalancecareers.com/what-is-aworkplace-1918295

Hove, M. \& Chenzi, V. (2020). Social media, civil unrest and government responses: The Zimbabwean experience. Journal of Contemporary Africa, 38(1), 121-137. https://doi.org/10.1080/02589001.2020.1746750

Hunger, M.B., Morosini, M.C., \& Stobäus, C.D. (2016). Teacher quality of life: Perspectives about their welfare. Creative Education, 7(16), 2363-2379. https:// doi.org/10.4236/ce.2016.716228

Hutton, W. (2011). Hutton review of fair pay in the public sector: Final report. London: Retrieved from http://www.nationalarchives.gov.uk/

Kakande, Y. (2015). Slave states: The practice of kafala in the Gulf Arab Region. New Alresford: John Hunt Publishers Ltd.

Kennedy, G. (2012). Economics. Retrieved from https://www.adamsmith.org

Korstjens, I., \& Moser, A. (2018). Series: Practical guidance to qualitative research. Part 4: Trustworthiness and publishing. European Journal of General Practice, 24(1) 120-124. https://doi.org/10.1080/13814788.2017.1375092

Mabhoyi, L.C. (2020). Labour relations among Zimbabwean teachers: Wellbeing and the challenges of professionals. International Journal of Teaching and Education 8(2), 53-76. https://doi.org/10.20472/TE.2020.8.2.004

Macleod, A. (2016). The impoverishment of the masses. Retrieved from https://www. goldmoney.com

Mandel, D. (2017). The intelligentsia and the October revolution. Retrieved from http://www.historicalmaterialism.org/

Marinette, B. (2018). The impact of working conditions on teacher attrition in secondary schools in the South West Region of Cameroon. International Journal of Construction Education and Research, 5(6), 59-78.

McCombes, S. (2020). Understanding different sampling methods. Retrieved from https://www.scribbr.com/methodology/sampling-methods/

McMahon, T. (2018). Inflation risk. Retrieved from https://inflationdata.com/ articles/2018/05/22/inflation-risk/

Mlambo, V.H., \& Adetibu, T.C. (2020). The brain drain of teachers in SA: Identifying the dynamics of its push factors. Journal of Social Sciences and Humanities, 17(1), 152-164.

Motowidlo, S.J., \& Kell, H.R. (2012). Chapter 5 job performance. Retrieved from https://scholar.google.com/scholar?q=Definition+of+job+performance\&btnG. $\mathrm{x}=51 \& \mathrm{btnG} . \mathrm{y}=11 \& \mathrm{hl}=\mathrm{en}$

Mthiyane, S., \& Chiororo, F. (2019). Chronicling the causes of school decline: The case of two Zimbabwean schools. African Education Review, 17(2), 73-87. https://doi. org/10.1080/18146627.2018.1514266

Munikwa, S., \& Mutungwe, E. (2011). Exploring the practice of extra lessons as offered in Chinhoyi urban secondary schools, Mashonaland West Province, Zimbabwe. Journal of Innovative Research in Management and Humanities, 2(1), 26-35. https://doi.org/10.4314/zjts.v1i1.65220

Ngwenya, V.C. (2015). The factors which motivate Zimbabwean teachers amid the economic challenges the country is confronted with. Journal of Social Science Studies, 2(2), 1-15. https://doi.org/10.5296/jsss.v2i2.7016

Ngwenya, V.C. (2020). Curriculum implementation challenges encountered by primary school teachers in Bulawayo Metropolitan Province, Zimbabwe. Africa Education Review, 17(2), 158-176. https://doi.org/10.1080/18146627.2018. 1549953

Nhundu, T.J. (1999). Stress in the teaching profession: A comparative study of sources, incidence and severity of occupational stress of teachers and head teachers in Zimbabwe. Zimbabwe Journal of Educational Research, 11(2), 1-29.

Ohide, A.D.F., \& Mbogo, R.W. (2017). Impact of working conditions on teacher's job satisfaction and performance in the private primary schools in Yei Town, South Sudan. International Journal of Education and Multidisciplinary Studies, 8(1), 122-129. https://doi.org/10.21013/jems.v8.n1.p12

Owens, R.G. (1995). Organizational behavior in education. New York, NY: Allyn and Bacon.

Portland Community College. (2015). Top 4 workplace issues that businesses are facing today: Continuous learning workplace issues for individuals, management and businesses. Retrieved from https://climb.pcc.edu/blog/top-4-workforceissues-that-businesses-are-facing-today

Shirrell, M., \& Reininger, M. (2017). School working conditions and changes in student teachers' planned in teaching. Teacher Education Quarterly, 44(2), 49-78. Retrieved from http://www.matthewshirrell.com/publications.htm

Shonk, K. (2019). Negotiation Strategies: Bernie Sanders' pragmatic approach to negotiating in the Senate. Retrieved from https://www.pon.harvard.edu/ 
Silverman, D. (2016). Qualitative research. London: Sage.

Steyn, G.M. (1996). Personnel management: Managing the quality of working life. Pretoria: University of South Africa.

Stoner, J.A., Freeman, R.E., \& Gilbert, Jr. D.R. (2008). Management. Englewood Cliff, NJ: Prentice Hall.

Tarisayi, K.S., Munyaradzi, E., \& Chidarikire, M. (2020). Micro commercialisation the new threat to teacher collegiality in Masvingo District. The Independent Journal of Teaching and Learning, 15(1), 91-100.
Wikipedia. (2020). Bulawayo. Retrieved from https://en.wikipedia.org/wiki/Bulawayo WiseGEEK. (2020). What is job performance? Retrieved from https://www.wisegeek. com/what-is-job-performance.htm

World Bank. (2016). Building quality school infrastructure for Chadian students and teachers. Retrievedfrom http://www.worldbank.org/en/news/feature/2016/06/16/ building-quality-school-infrastructure-for-chadian-students-and-teachers

World Development Bank. (2013). Malawi - Public expenditure review (English). Washington, DC: World Bank Group. 